\title{
Can sodium bicarbonate really help in treating metabolic acidosis caused by aluminium phosphide poisoning?
}

\author{
Sayed Mahdi Marashi ${ }^{1}$ and Zeynab Nasri-Nasrabadi ${ }^{2}$ \\ Trauma Research Center, Shiraz University of Medical Sciences, Shiraz ${ }^{l}$, Department of Pediatrics, Children's Medical \\ Center, Pediatric Center of Excellence, Tehran University of Medical Sciences, Tehran ${ }^{2}$, Iran
}

Management of aluminium phosphide (AlP) poisoning seems to have seen some changes over the recent years (1). We believe that one of the reasons was the review article (2) and letters to the editor (3-5) published in your journal between 2012 and 2013. However, we still face problems in treating severe cases, who generally present with refractory metabolic acidosis and whose prognosis is poor (6). To combat this life-threatening complication, some recommend administration of large amounts of sodium bicarbonate $\left(\mathrm{NaHCO}_{3}\right)(7)$, but our experience is that this strategy does not address the problem.

Even though controversy continues about the exact mechanism of AlP toxicity and metabolic acidosis, all agree that AlP toxicity leads to $\mathrm{H}^{+}$ion efflux from the cell and, when $\mathrm{H}^{+}$diffuses outside the cells, to metabolic acidosis (2, 8-11).

When administered, sodium bicarbonate splits into $\mathrm{Na}^{+}$ and $\mathrm{HCO}_{3}^{-}$ions in the extracellular compartment. However, as the cell membrane prevents $\mathrm{HCO}_{3}^{-}$ions to enter the cell, the increase in extracellular $\mathrm{pH}$ does not counter intracellular acidosis. Moreover, bicarbonate and $\mathrm{H}^{+}$ions react together in the acidic medium and produce carbonic acid, which dissociates to $\mathrm{H}_{2} \mathrm{O}$ and $\mathrm{CO}_{2}$, and $\mathrm{CO}_{2}$ can readily diffuse across the cell membrane. The only defence against increased $\mathrm{CO}_{2}$ is hyperventilation, which usually is not sufficient to prevent $\mathrm{CO}_{2}$ from accumulating within the cell. At high enough concentrations, $\mathrm{CO}_{2}$ will react with $\mathrm{H}_{2} \mathrm{O}$ to produce carbonic acid (10) and intensify intracellular acidosis.

Graf et al. (12) tested the treatment of lactic acidosis with sodium bicarbonate in dogs. They have found that visceral, intracellular, and arterial $\mathrm{pH}$ drops, presumably due to increased lactate production and $\mathrm{CO}_{2}$ load. They also observed a continuous decrease in visceral blood flow rate. It seems that the sole benefit of sodium bicarbonate administration in acidosis is that it may improve heart

Correspondence to: Zeynab Nasri-Nasrabadi, Department of Paediatrics, Tehran University of Medical Sciences, 16 Azar Avenue, Tehran, Iran, E-mail: drmr44@yahoo.com preload and increase the tonicity of the intravascular fluid. Furthermore, Cooper et al. (13) reported no beneficial haemodynamic effect of sodium bicarbonate in patients with severe lactic acidosis.

The conservative opinion about acidosis treatment is not to discourage the use of sodium bicarbonate as a routine medication $(11,14,15)$. Dellinger et al. (16) found no evidence supporting routine use of bicarbonate therapy in severe sepsis and consequently hypoperfusion-induced lactic acidosis. However, they do not disagree with the use of sodium bicarbonate in patients whose $\mathrm{pH}$ is lower than 7.15. A survey conducted by Kraut and Kurtz (17) has indicated that two-thirds of critical care and nephrology physicians decide to administrate a base (mostly sodium bicarbonate) when acidosis becomes severe ( $\mathrm{pH}$ below 7.00). They generally believe the initial efforts must concentrate on correcting the underlying disease.

Our experience is that patients with AlP poisoning and induced shock with arterial $\mathrm{pH}>7.00$ require administration of 500 to $1000 \mathrm{~mL}$ of hydroxyethyl starch, which can effectively resolve symptoms of shock and significantly increase arterial $\mathrm{pH}$ without additional administration of sodium bicarbonate.

\section{REFERENCES}

1. Agrawal VK, Bansal A, Singh RK, Kumawat BL, Mahajan P. Aluminum phosphide poisoning: Possible role of supportive measures in the absence of specific antidote. Indian J Crit Care Med. 2015;19:109-12. doi: 10.4103/09725229.151019 .

2. Mehrpour O, Jafarzadeh M, Abdollahi M. A systematic review of aluminium phosphide poisoning. Arh Hig Rada Toksikol 2012;63:61-73. doi: 10.2478/10004-1254-63-20122182

3. Nasri Nasrabadi Z, Marashi SM. Comments on "A systematic review of aluminium phosphide poisoning". Arh Hig Rada Toksikol 2012;63:551. doi: 10.2478/10004-1254-63-20122321

4. Marashi SM, Majidi M, Sadeghian M, Ahmadi S, Raji Asadabadi H, Nasri Nasrabadi Z. Is the use of cardioactive 
steroids appropriate in managing aluminium phosphide poisoning-induced heart failure? Arh Hig Rada Toksikol 2013;64:477-8. doi: 10.2478/10004-1254-64-2013-2439

5. Marashi SM, Majidi M, Raji Asadabadi H, Nasri Nasrabadi Z. A common misconception in the management of aluminium phosphide poisoning. Arh Hig Rada Toksikol 2013;64:475-6. doi: 10.2478/10004-1254-64-2013-2404

6. Louriz M, Dendane T, Abidi K, Madani N, Abouqal R, Zeggwagh AA. Prognostic factors of acute aluminum phosphide poisoning. Indian J Med Sci 2009;63:227-34. doi: 10.4103/0019-5359.53386

7. Jaiswal S, Verma RK, Tewari N. Aluminum phosphide poisoning: effect of correction of severe metabolic acidosis on patient outcome. Indian J Crit Care Med 2009;13:21-4. doi: 10.4103/0972-5229.53111

8. Marashi SM, Arefi M, Behnoush B, Nasrabad MG, Nasri Nasrabadi Z. Could hydroxyethyl starch be a therapeutic option in management of acute aluminum phosphide toxicity? Med Hypotheses 2011;76:596-8. doi: 10.1016/j. mehy.2011.01.009

9. Anand R, Binukumar BK, Gill KD. Aluminum phosphide poisoning: an unsolved riddle. J Appl Toxicol 2011;31:499505. doi: 10.1002/jat.1692

10. Marashi SM, Majidi M, Sadeghian M, Jafarzadeh M, Mohammadi S, Nasri Nasrabadi Z. Protective role of coenzyme Q10 as a means of alleviating the toxicity of aluminum phosphide: An evidence-based review. Tzu Chi Med J 2015, in press. doi: 10.1016/j.tcmj.2014.12.002 [displayed online since 7 February 2015] Available at: http:// www.tzuchimedjnl.com/article/S1016-3190(14)00123-2/ fulltext

11. Boyd JH, Walley KR. Is there a role for sodium bicarbonate in treating lactic acidosis from shock? Curr Opin Crit Care 2008;14:379-83. doi: 10.1097/MCC.0b013e3283069d5c

12. Graf H, Leach W, Arieff AI. Metabolic effects of sodium bicarbonate in hypoxic lactic acidosis in dogs. Am J Physiol 1985;249(5 Pt 2):F630-5. PMID: 2998202
13. Cooper DJ, Walley KR, Wiggs BR, Russell JA. Bicarbonate does not improve hemodynamics in critically ill patients who have lactic acidosis. A prospective, controlled clinical study. Ann Intern Med 1990;112:492-8. PMID: 2156475

14. Gehlbach BK, Schmidt GA. Bench-to-bedside review: treating acid-base abnormalities in the intensive care unit the role of buffers. Crit Care 2004;8:259-65. doi: 10.1186/ $\operatorname{cc} 2865$

15. Forsythe SM, Schmidt GA. Sodium bicarbonate for the treatment of lactic acidosis. Chest 2000;117:260-7. PMID: 10631227

16. Dellinger RP, Levy MM, Carlet JM, Bion J, Parker MM, Jaeschke R, Reinhart K, Angus DC, Brun-Buisson C, Beale R, Calandra T, Dhainaut JF, Gerlach H, Harvey M, Marini JJ, Marshall J, Ranieri M, Ramsay G, Sevransky J, Thompson BT, Townsend S, Vender JS, Zimmerman JL, Vincent JL, International Surviving Sepsis Campaign Guidelines Committee; American Association of Critical-Care Nurses; American College of Chest Physicians; American College of Emergency Physicians; Canadian Critical Care Society; European Society of Clinical Microbiology and Infectious Diseases; European Society of Intensive Care Medicine; European Respiratory Society; International Sepsis Forum; Japanese Association for Acute Medicine; Japanese Society of Intensive Care Medicine; Society of Critical Care Medicine; Society of Hospital Medicine; Surgical Infection Society; World Federation of Societies of Intensive and Critical Care Medicine: Surviving Sepsis Campaign: international guidelines for management of severe sepsis and septic shock: 2008. Crit Care Med 2008;36:296-327.

17. Kraut JA, Kurtz I. Use of base in the treatment of acute severe organic acidosis by nephrologists and critical care physicians: results of an online survey. Clin Exp Nephrol 2006;10:1117. PMID: 16791396 